\title{
Development and Effects of Jamun Seed Powder Incorporated Cookies
}

\author{
Abinaya Kannan ${ }^{1}$, Yamuna Devi Puraikalan² \\ ${ }^{1}$ M.Phil Research Scholar, Department of Home Science, Mother Teresa Women’s University, Kodaikanal, India \\ ${ }^{2}$ M.Phil, Phd, Assistant Professor, Department of Home Science, Mother Teresa Women's University, Kodaikanal, India
}

\begin{abstract}
The present study was to formulate the jamun seed powder incorporated cookies by incorporation of different level of jamun seed powder like 5\%, 10\% and 15\% into cookies. The Organoleptic properties of the formulated cookies like colour, appearance, flavour, viscosity, taste and over all acceptability were evaluated. Among the different incorporation $10 \%$ of jamun seed powder incorporated cookies were recorded the highest scores for overall acceptability.
\end{abstract}

Keywords: Jamun seed powder and vitamin-C and Iron

\section{Introduction}

Jamun (Syzygium Cumini) is always appreciated for the colour, flavour and taste of its fruit. It is very large tropical tree that belongs to Myrtaceae family and known by synonyms jambolan or black plum. In India, the jamun tree and its fruit are known variously as Jamun, Jambul, Jaamoon, Jambul [1]. Worldwide, it is known by some other names like Java Plum, Black Plum, Indian blackberry, Portuguese Plum, Jambolan Plum etc. The jamun tree is native to India and its bordering countries like Nepal, Pakistan, Bangladesh Sri Lanka and even Indonesia. The tree grows equally well in both the tropical and the sub tropical regions. Thereafter, with the onset of monsoon in June it starts bearing fruit. The flowers are white and have a sweet fragrance. Jambul fruits resemble oblong or ovoid in shape. They have a single seed and a soft dark purple coloured almost black skin and a lighter purple flesh [2]. When eaten, the fruits coat the mouth and the tongue a deep purple colour that stays for a few hours. The fruit is sweet and tart and leaves a slight astringent action in the mouth.

All the parts of the jamun or Jambul tree find a wide variety of uses. Jams, jellies, squashes, preserves, vinegar, beverages, pickles and wine are made from the jamun fruits [3]. The seeds of jamun is of great benefit when it comes to lowering of blood glucose level and reduces glycouria. It also contains Vitamins C \& A, riboflavin, nicotinic acid, choline, folic acid, malaic acid, sodium, potassium, calcium, phosphorus, manganese, zinc and iron [4]. Anthocyanins are present in appreciable quantities and are the reason for the antioxidant activity of the fruit. Jamun seed powder is used to treat diabetes by several traditional practitioners. Scientifically, it has a low glycemic index, making it a good option for diabetics. Anti-diabetic effects of jamun seed, suggesting that it holds significant potential to produce safer drugs for diabetes treatment another study showed that jamun seeds could lower blood sugar levels by $30 \%$ [5]. The seed is associated with lowered risk of secondary complications of diabetes. The real benefit is at the stage of IFG (Impaired fasting glucose) which can be well-controlled with Jamun seed, Regulation of IFG prevents the early onset of diabetes and further conditions [6]
It is a good source of mineral salts. calcium $15 \mathrm{mg}$, potassium $55 \mathrm{mg}$, magnesium $35 \mathrm{mg}$, phosphorus $15 \mathrm{mg}$, sodium $26.2 \mathrm{mg} / 100 \mathrm{~g}$ fruit and vitamin C $18 \mathrm{mg} / 100 \mathrm{~g}$ of fruit. It provides $62 \mathrm{Kcal}$ energy per $100 \mathrm{~g}$ of edible fruit. It contains good amount of carotene (48 mg/100 g), folic acid (3 mg/100 g) [7]. Jamun fruit, particularly those from Pakistan's Punjab region, help in breast cancer treatments as it seems to inhibit the proliferation of breast cancer cell lines [8].

These could be possibly due to several bioactive Phytochemicals including polyphenols which have the purple pigment called anthocyanin. Studies show that consumption of jamun seed powder may also provide benefits during chemotherapy and radiation. Jamun seed has adequate amount of iron and vitamin C. The presence of iron in the black plum is good to increase the haemoglobin count. Jamun seed iron content acts as blood purifying agent. Since, it is the medium of purifying blood; therefore, it is good for skin and beauty. Iron content is beneficial in menses where the woman faces blood loss. People suffering from anaemia and jaundice should consume jamun seed because of its high iron content [9].

\section{Materials and Methods}

Purple coloured jamun were selected for the preparation of the jamun seed powder. Jamun were initially cleaned and then cut into pieces. The stem part was discarded and seeds were taken apart and sun dried. The dried jamuns seeds were powdered in the processor and made it cool and incorporated into cookies with different level of incorporation. The products were stored in a hygienic manner. The treatments for preparation of jamun seed powder cookies were as follows;

\section{Treatment Details}

T1 - Cookies flour (Control)

$\mathrm{T} 2$ - Cookies flour $+5 \%$ of Jamun seed powder

$\mathrm{T} 3-$ Cookies flour $+10 \%$ of Jamun seed powder

$\mathrm{T} 4$ - Cookies flour $+15 \%$ of Jamun seed powder 


\section{International Journal of Science and Research (IJSR) \\ ISSN (Online): 2319-7064 \\ Index Copernicus Value (2013): 6.14 | Impact Factor (2015): 6.391}

The formulated cookies were prepared with specified amount of jamun seed powder as mentioned in above treatments. All the ingredients such as sugar, butter were used.

Organoleptic evaluation of jamun seed incorporated cookies were carried out by 10 am among the semi-trained panel judges of thirty numbers including the staff and postgraduate nutrition students, Department of Home science, Mother Teresa Women's University, and IGNOU (The Indira Gandhi National Open University), Chennai. The jamun seed incorporated cookied were placed for onset evaluation. The specific sensory characteristics of cookies viz., crunchiness, porosity, sweetness, baking quality with other general characteristics viz., colour, aroma, taste, mouth feel and over all acceptability were evaluated using a rating scale. The mean Scores given by sixty judges were used for statistical analysis.

\section{Results and Discussion}

The Organoleptic properties of cookies were evaluated visually, palpatory, gustatory, olfactory, and overall acceptability. The statistical analyses of the data were depicted in the Table I. The overall acceptability and 9 point rating scale score was higher for the $10 \%$ incorporation of jamun seed powder. The data reveals that there were significant differences at the level of $1 \%$ significances among $10 \%$.

\section{Conclusion}

The wide spread popularity of cookies from all age groups makes this product, a good option for selection. It improves vitamin-C and Iron and reduces diabetes and cancer and anaemia. Furthermore it reduces histamine production to prevent or ease allergies and asthma. This formulated cookie is convenience food can surely serve as suitable vehicle for improving nutrient intake without compromising its Organoleptic properties. It will indirectly improve the vitamin- $\mathrm{C}$ and Iron intake of its consumers. The product has excellent market potential since it contain low carbohydrate, high vitamin-C and Iron, and sufficient amount of vitamin and mineral content. Considering all these beneficial factors the jamun seed based other products must be most concern. New steps must be taken to undergo research about nutritive value of jamun fruit and its part and to introduce it to all community.

Table 1: Results of Statistical analysis of scores given by panel judges for the vitamin-C and Iron rich jamun seed incorporated cookies

\begin{tabular}{|c|c|c|c|c|}
\hline S.NO & $\begin{array}{c}\text { Level of } \\
\text { incorporation }\end{array}$ & Mean \pm S.D & t-value & $\begin{array}{c}\text { Level of } \\
\text { significance }\end{array}$ \\
\hline 1 & Control & $78.5 \pm 6.26$ & 10.53 & Not significant \\
\hline 2 & $5 \%$ & $77.7 \pm 10.10$ & 10.10 & Not significant \\
\hline 3 & $10 \%$ & $79 \pm 3.7$ & 1.920 & $1 \%$ \\
\hline 4 & $11 \%$ & $75 \pm 2.0$ & 10.92 & Not significant \\
\hline
\end{tabular}

\section{References}

[1] Ayyanar M, Subash-Babu P, Ignacimuthu S. Syzygium cumini (L.) Skeels a novel therapeutic agent for diabetes: folk medicinal and pharmacological evidences.

[2] Complement There Med. 2013 Jun; 21(3):232-43. doi: 10.1016/j.ctim.2013.03.004. Epub 2013 Apr 25.

[3] Helmstadter A 2008 Feb. Syzygium cumini (L.) SKEELS (Myrtaceae) against diabetes-125 years of research. Pharmazie; 63(2):91-101.

[4] Janick, Jules. Paull, Robert E 2008. The Encyclopaedia of Fruit \& Nuts. Publisher: CABI

[5] Jagetia GC, Baliga MS, Venkatesh P 2005 March. Influence of seed extract of Syzygium Cumini (Jamun) on mice exposed to different doses of gamma-radiation. $\mathrm{J}$ Radiat Res; 46(1):59-65.

[6] Reynertson KA, Basile MJ, Kennelly EJ April 2005. Antioxidant potential of seven myrtaceous fruits Ethnobot Res.

[7] Lago ES, Gomes E, da Silva R 2004. Extraction and anthocyanic pigment quantification of the Jamun fruit (Syzygium cumini Lam).

[8] Shafi PM, Rosamma MK, Jamil K, Reddy PS 2002. Antibacterial activity of Syzygium cumini and Syzygium travancoricum leaf essential oils. Fitoterapia; 73:414416.

[9] H. Sagrawat A, Mann and M. Kharya, 2006. "Pharmacological Potential of Eugenia Jambolana: A Review,” Pharmacogenesis Magazice, Vol. 2

\section{Author Profile}

Abinaya Kannan received B.Sc and M.Sc degrees in food and nutrition from Ethiraj College for Women in 2013 and Mother Teresa Womens University in 2015. 